\title{
ANALYSIS OF THE ENERGY POTENTIAL OF SOLAR LIGHT OF THE WESTERN REGION OF UKRAINE WITH THE ACCOUNT OF CLIMATIC CONDITIONS
}

\author{
Vladimir Andreychuk \\ Department of Lighting Engineering and Electrical Engineering \\ Ternopil Ivan Puluj National Technical University \\ 46 Mikulinetska str., Ternopil, Ukraine, 46005 \\ Andriychukv@rambler.ru \\ Yaroslav Filyuk \\ Department of Lighting Engineering and Electrical Engineering \\ Ternopil Ivan Puluj National Technical University \\ 46 Mikulinetska str., Ternopil, Ukraine, 46005 \\ filuk.slavik.91@gmail.com
}

\begin{abstract}
An experimental facility for measuring and recording the flux density of solar radiation is designed and installed. An electrical circuit is developed and a pyranometer model is developed to measure the level of solar radiation, and it is graduated with a Soler Power Meter DT-1307 solar radiation flux meter. The time distribution of the flux density of solar energy is analyzed and the surface energy density of solar radiation is calculated for Ternopil. The influence of climatic conditions on the energy of solar radiation is determined. Analytical dependencies are obtained on the basis of comparison of the measured values of the flux density of solar radiation and the cloud cover taken from meteorological services. The energy potential of solar radiation during 2012-2015 in the western region of Ukraine is calculated, as well as the average monthly and average annual energy density of solar radiation. It is determined that the annual average density of the solar energy flux is $1045.9 \mathrm{~kW} \cdot \mathrm{h} / \mathrm{m}^{2}$, and its deviation does not exceed $5 \%$. It is shown that the most favorable months for the use of solar energy are from March to September of each year.
\end{abstract}

Keywords: solar energy flux density, energy potential, cloudiness degree, pyranometer, microcontroller.

\section{Introduction}

A characteristic feature of modern energy systems is the movement towards the development of clean energy based on non-traditional and renewable energy sources. One of the most promising areas is solar energy. In Ukraine, there are quite favorable conditions for the use of solar energy. When studying the energy potential of solar radiation, it is necessary to take into account not only the coordinates of the terrain, but also climatic conditions. At present, there is the data of weather services for regional and district centers for the whole territory of Ukraine. They are represented by temperature, cloudiness, wind speed, cloud height, atmospheric pressure of the region [1]. Among them there is no data on the flux of solar radiation. There is the task to establish a connection between the meteorological conditions of the terrain and the flow of solar energy.

The aim of research is measuring the energy potential of solar radiation, taking into account the climatic conditions of the Ternopil region. Establishment of a connection between meteorological data and the density of energy flux of solar radiation, which will allow to determine the energy potential of the western region of Ukraine.

Formulation of the problem. Development of a technique and manufacturing of an experimental facility for measuring the energy potential of solar radiation and recording it in real time. Calculation of the energy flux density of solar radiation during the day and establishing its dependence on the degree of cloudiness.

\section{Materials and methods}

When analyzing the intensity of solar radiation, it is assumed that the total monthly solar energy falling on a horizontal surface, although changing annually, but their average value does 
not change $[2,3]$. In $[4,5]$, the monthly and annual values of the total solar energy falling on the horizontal surface are obtained, calculated using the calculation method, taking into account the duration of sunlight and mean cloudiness. The results of calculations of the total, direct and scattered flux of solar radiation on a horizontal surface for Ternopil are presented in [6], but it does not have data from experimental studies that take into account the specific climatic conditions of a given territory.

There are theoretical and semiempirical models created on the correlation of the flux density of solar energy with the cloudiness and transparency of the atmosphere and the transmission characteristics of various parts of the solar spectrum [7, 8]. In [9], probabilistic characteristics and laws of the distribution of the solar potential are calculated for the territory of the Kirovograd region. The paper [10] shows the mean values of solar energy for each month from 2012 to 2015 in Odessa, but they are not typical for the northern and western regions of Ukraine.

\section{Experiment for measuring and recording of solar radiation}

According to the intensity of solar radiation, four zones are allocated in Ukraine: the first $\left(1350 \mathrm{~kW} \cdot \mathrm{h} / \mathrm{m}^{2}\right.$ per year) and the second $\left(1250 \mathrm{~kW} \cdot \mathrm{h} / \mathrm{m}^{2}\right.$ per year), which are in the south of Ukraine and occupy more than half of its territory; the third one $\left(1150 \mathrm{~kW} \cdot \mathrm{h} / \mathrm{m}^{2}\right.$ per year), which occupies the regions of the western region and the fourth zone $\left(1000 \mathrm{~kW} \cdot \mathrm{h} / \mathrm{m}^{2}\right.$ per year), which is located in the northern and central regions of Ukraine and is least favorable for the use of solar energy $[11,12]$. To analyze the energy potential of solar radiation in the western region, the territory of the Ternopil region was taken with the center in the city of Ternopil. For this purpose, an experimental facility was developed for measuring the flux density of solar radiation, the block diagram of which is shown in Fig. 1.

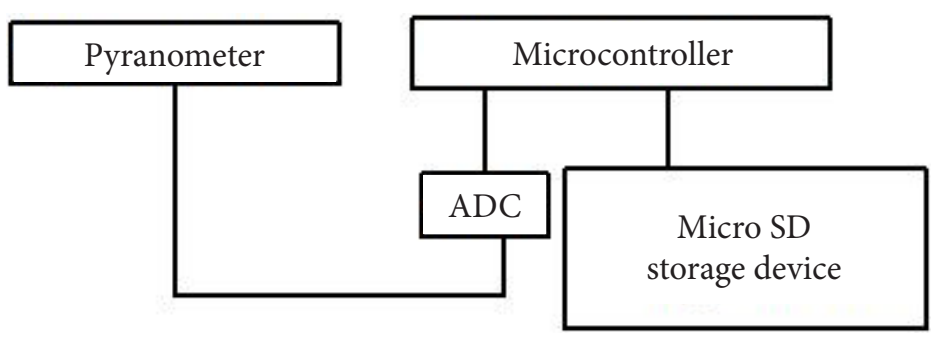

Fig. 1. Block diagram of experimental facility

The facility includes: pyranometer, which measures the flux density of solar radiation; Microcontroller Atmega 32A (ATMEL, China), which processes and records received data from an analog-to-digital converter (ADC); Micro SD storage device (Kingston, China). This facility allows to measure and record the flow of solar radiation in real time at intervals of $1 \mathrm{~min}$ to the drive as a separate file during the day.

The pyranometer consists of: photodetector made of single-crystal silicon; current-to-voltage conversion unit and signal amplifying unit. The photodetector operated in short-circuit mode and was graduated with a Soler Power Meter DT-1307 (CEM, China). Measurements were performed at an angle of inclination of the photodetector surface to the horizon $\alpha=49^{\circ}$, which is optimal for the latitude of the given territory [6]. The results were processed using the Matlab software environment, averaging the data by the least squares method.

All researches were carried out on the basis of the Faculty of Applied Information Technologies and Electrical Engineering of Ternopil Ivan Puluj National Technical University, Mikulinetska str. 46 , geographical coordinates $-49,53^{\circ}$ north latitude and $25.6^{\circ}$ east longitude. The facility was located on the upper terrace of Building \#7, did not create artificial shading and allowed to obtain the most objective measurement results. Appearance of the experimental facility is shown in Fig. 2. 


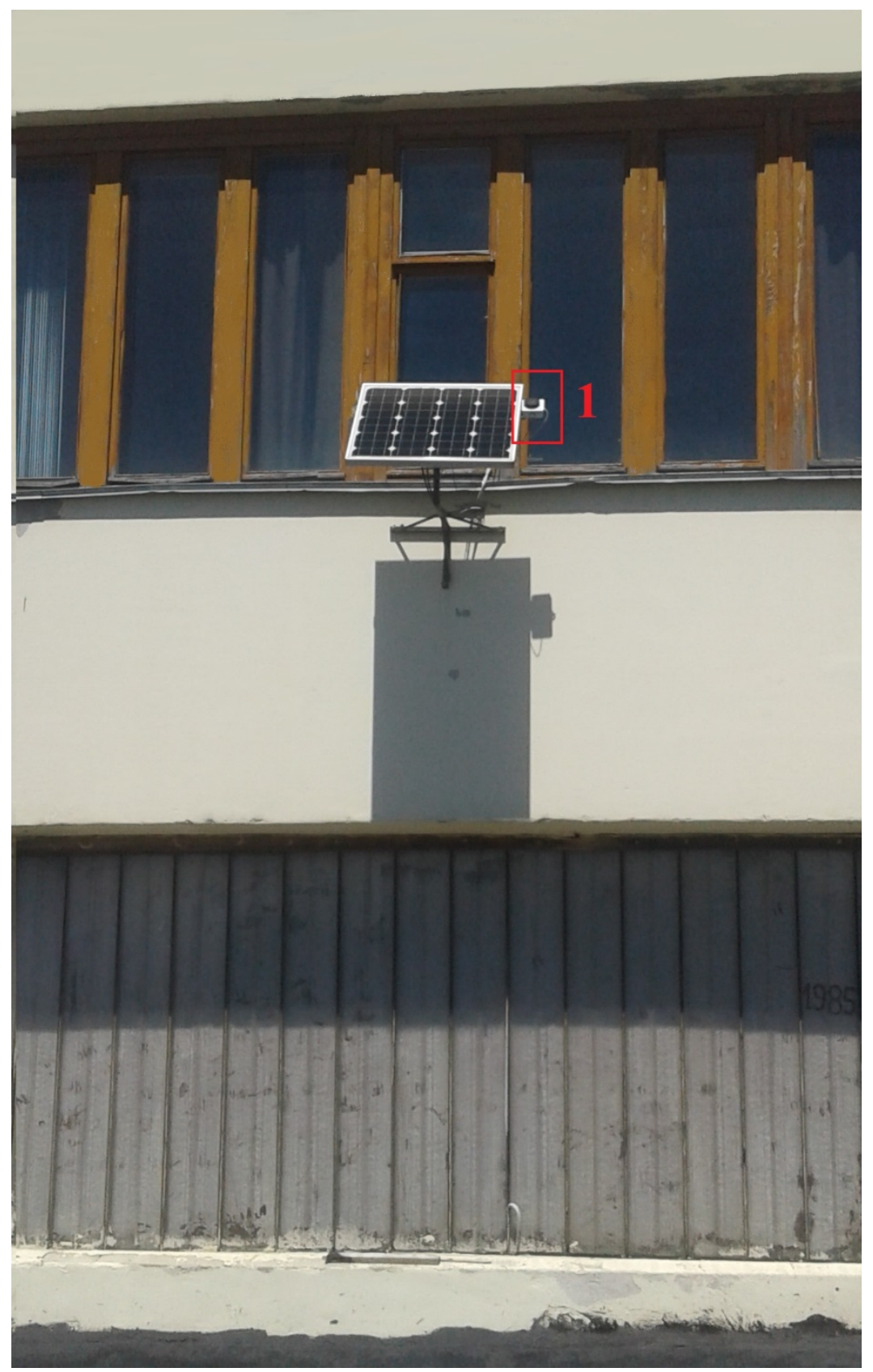

Fig. 2. Appearance of experimental facility: 1 - pyranometer

\section{Research results of the energy potential of the western region of Ukraine}

The results of measurements of the flux density of solar radiation were averaged overnight during each month of 2016 and recorded in the created database. This also included data on the cloudiness degree taken from the weather service website [1]. Clouds were represented in points from 0 (clear) to 10 (cloudy). Fig. 3 shows the distribution of the radiation flux density for the solar, cloudy and mostly cloudy period of August 2016. The energy density of solar radiation during the day was calculated from the dependences obtained: $E=6.9 \mathrm{~kW} \cdot \mathrm{h} / \mathrm{m}^{2}$ for solar; $\mathrm{E}=3,7 \mathrm{~kW} \cdot \mathrm{h} / \mathrm{m}^{2}$ for cloudy; $\mathrm{E}=2,2 \mathrm{~kW} \cdot \mathrm{h} / \mathrm{m}^{2}$ - a mostly cloudy day. Similar calculations were made for other months.

To find the connection between the solar energy flow and the climatic conditions of the terrain, a comparison was made of the results of measurements of the flux density of solar energy to cloud data, which were taken from the weather service website. The deviation of the results of comparing the averaged values of the measured flux of solar energy and the degree of cloudiness 
for a three-hour interval and an interval of one day did not exceed $5 \%$. This allowed to use the average daily values of these parameters for further calculations. The mean cloudiness and mean flux density of solar radiation were calculated from the average of their arithmetic mean.

Fig. 4 shows the dependence of the energy density of solar radiation per day of average cloudiness for August 2016.
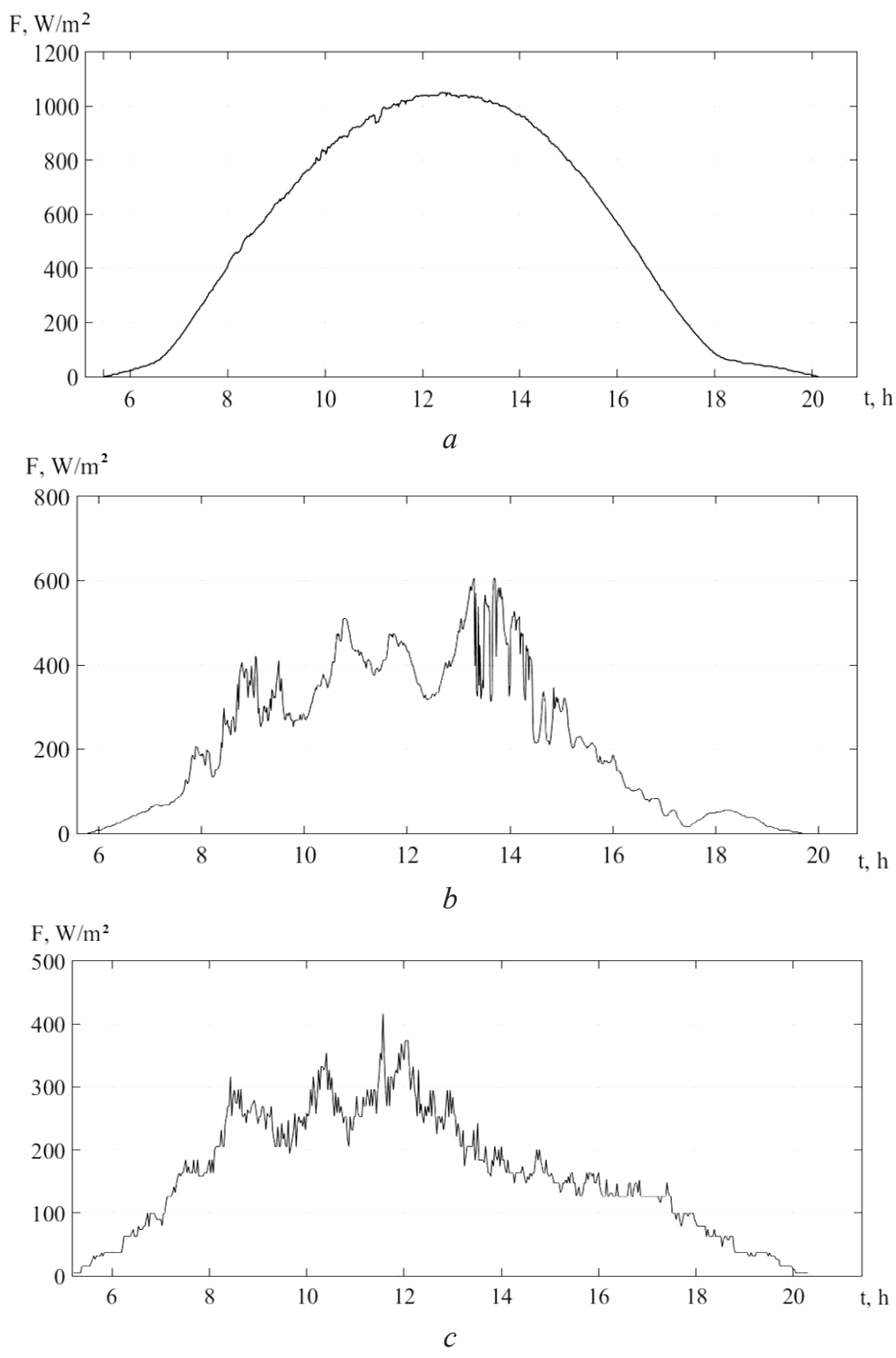

Fig. 3. The graph of the change in the flux density of solar radiation during the day of August 2016, $a$ - solar; $b$ - cloudy; $c$ - mostly cloudy day

The graph is constructed using a least-squares averaging. As a result, a linear dependence is obtained, described by the equation:

$$
\mathrm{E}_{\mathrm{av}}=-0,67 \cdot \mathrm{N}+7,19
$$

where $\mathrm{E}$ - solar energy $\mathrm{kW} \cdot \mathrm{h} / \mathrm{m}^{2}$, during one day; $\mathrm{N}$ - cloudiness.

Given that the duration of sunshine during the day and the angle of the sun's inclination to the horizon change throughout the year, the same measurements were made for each month of 016 . 
Their results are given in Table 1. Microsoft Excel 2010 software was used for calculations and data processing.

Algorithm of calculations: creation of an array of cloud data and data of measurements of the solar energy flow; data averaging; plotting the dependences of the solar energy $\mathrm{E}(\mathrm{N})$ on cloudiness; an analytical expression for the dependence $\mathrm{E}(\mathrm{N})$; calculation of the average daily and total energy of solar radiation during the month and year.

Table 1 shows the values of the total energy of solar radiation E during the month, the average daily values for each month of the $\mathrm{E}_{\mathrm{av}}$, as well as the analytical dependences of the average daily flux of solar energy on the average cloudiness $E_{a v}=f(N)$.

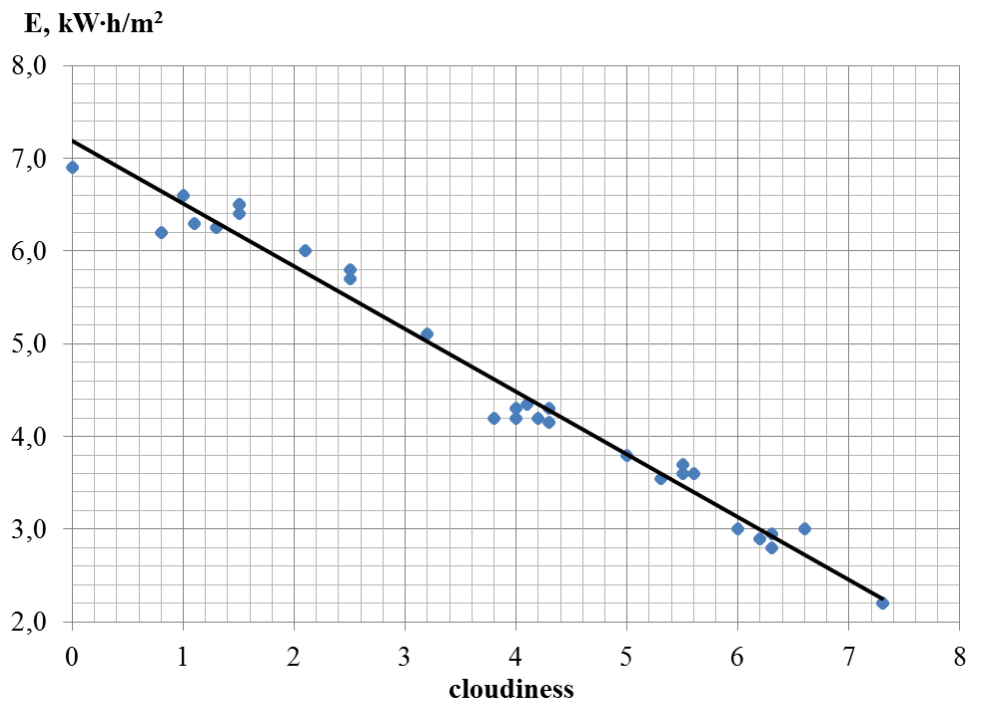

Fig. 4. Graph of the dependence of the energy density of solar radiation per day on cloudiness

Table 1

The monthly and average daily energy of solar radiation and the analytical dependences of the average daily flux density of solar energy from the mean cloudiness

\begin{tabular}{cccc}
\hline Month & $\mathbf{E}, \mathbf{k W} \cdot \mathbf{h} / \mathbf{m}^{2}$ & $\mathbf{E}_{\mathbf{a v}}, \mathbf{k W} \cdot \mathbf{h} / \mathbf{m}^{2}$ & $\mathbf{E}_{\mathbf{a v}}=\mathbf{f}(\mathbf{N})$ \\
\hline January & 45 & 1,4 & $\mathrm{E}_{\mathrm{av}}=-0,386 \times \mathrm{N}+4,0385$ \\
February & 65 & 2,2 & $\mathrm{E}_{\mathrm{av}}=-0,3871 \times \mathrm{N}+4,7581$ \\
March & 82,4 & 2,6 & $\mathrm{E}_{\mathrm{av}}=-0,5095 \times \mathrm{N}+5,814$ \\
April & 105,2 & 3,5 & $\mathrm{E}_{\mathrm{av}}=-0,5334 \times \mathrm{N}+6,455$ \\
May & 134,7 & 4,3 & $\mathrm{E}_{\mathrm{av}}=-0,5467 \times \mathrm{N}+6,2689$ \\
June & 136,7 & 4,5 & $\mathrm{E}_{\mathrm{av}}=-0,5575 \times \mathrm{N}+7,0102$ \\
July & 144 & 4,6 & $\mathrm{E}_{\mathrm{av}}=-0,5575 \times \mathrm{N}+7,0102$ \\
August & 141,3 & 4,5 & $\mathrm{E}_{\mathrm{av}}=-0,677 \times \mathrm{N}+7,1902$ \\
September & 100,7 & 3,3 & $\mathrm{E}_{\mathrm{av}}=-0,6072 \times \mathrm{N}+5,9676$ \\
October & 48,7 & 1,6 & $\mathrm{E}_{\mathrm{av}}=-0,4736 \times \mathrm{N}+4,567$ \\
November & 38,3 & 1,3 & $\mathrm{E}_{\mathrm{av}}=-0,4 \times \mathrm{N}+4,195$ \\
December & 35,4 & 1,1 & $\mathrm{E}_{\mathrm{av}}=-0,32 \times \mathrm{N}+3,263$
\end{tabular}

Based on the obtained analytical dependencies and weather data, the mean monthly energy density of solar radiation for 2012-2015 is calculated, the data are presented in Table 2 . The total 
annual and average daily energy of solar radiation are also calculated. The total annual energy for a given period ranges between $994.4-1077.7 \mathrm{~kW} \cdot \mathrm{h} / \mathrm{m}^{2}$.

Table 2

The energy density of solar radiation for 2012-2016 years

\begin{tabular}{|c|c|c|c|c|c|c|}
\hline Month & $\begin{array}{c}2016 \\
\mathbf{E}, \mathbf{k W} \cdot \mathbf{h} / \mathbf{m}^{2}\end{array}$ & $\begin{array}{c}2015 \\
\mathrm{E}, \mathrm{kW} \cdot \mathbf{h} / \mathrm{m}^{2}\end{array}$ & $\begin{array}{c}2014 \\
\mathrm{E}, \mathrm{kW} \cdot \mathbf{h} / \mathrm{m}^{2}\end{array}$ & $\begin{array}{c}2013 \\
\mathrm{E}, \mathrm{kW} \cdot \mathbf{h} / \mathrm{m}^{2}\end{array}$ & $\begin{array}{c}2012 \\
\mathrm{E}, \mathrm{kW} \cdot \mathbf{h} / \mathrm{m}^{2}\end{array}$ & $\begin{array}{c}\text { Average value } \\
\mathrm{E}, \mathbf{k W} \cdot \mathbf{h} / \mathbf{m}^{2}\end{array}$ \\
\hline January & 45 & 44 & 39,3 & 45 & 55 & 45,7 \\
\hline February & 65 & 71,3 & 68,9 & 58,6 & 76,5 & 68,1 \\
\hline March & 82,4 & 98,9 & 98,5 & 81,3 & 102,2 & 92,7 \\
\hline April & 105,2 & 112,9 & 100,9 & 119,5 & 108,2 & 109,4 \\
\hline May & 134,7 & 113,9 & 101,5 & 107,8 & 110 & 113,6 \\
\hline June & 136,7 & 133,6 & 118,9 & 123,3 & 123,3 & 127,2 \\
\hline July & 144 & 133,3 & 121,7 & 129,7 & 138,1 & 133,4 \\
\hline August & 141,3 & 136,7 & 123,1 & 129,9 & 125,3 & 131,3 \\
\hline September & 100,7 & 75,3 & 102,6 & 66,9 & 94,6 & 88 \\
\hline October & 48,7 & 56,2 & 72,3 & 51,8 & 51,3 & 56,1 \\
\hline November & 38,3 & 47,3 & 45,5 & 42,1 & 38,5 & 42,3 \\
\hline December & 35,4 & 48 & 32,9 & 38,5 & 36,6 & 38,3 \\
\hline Total annual energy & 1077,7 & 1071,7 & 1026,3 & 994,4 & 1059,7 & 1045,9 \\
\hline Daily average value & 2,94 & 2,93 & 2,81 & 2,72 & 2,9 & 2,9 \\
\hline
\end{tabular}

On the basis of these data, the average annual energy of solar radiation in the western region of Ukraine is determined, which is $1045.9 \mathrm{~kW} \cdot \mathrm{h} / \mathrm{m}^{2}$. The graph of the change in the flux density of solar energy during 2012-2016 years is shown in Fig. 5. As can be seen from the graph, the most favorable months for the use of solar energy is from March to September each year. On the basis of the obtained data, a graph of the change in the average annual value of the flux density of solar energy is constructed, which is shown in Fig. 6.

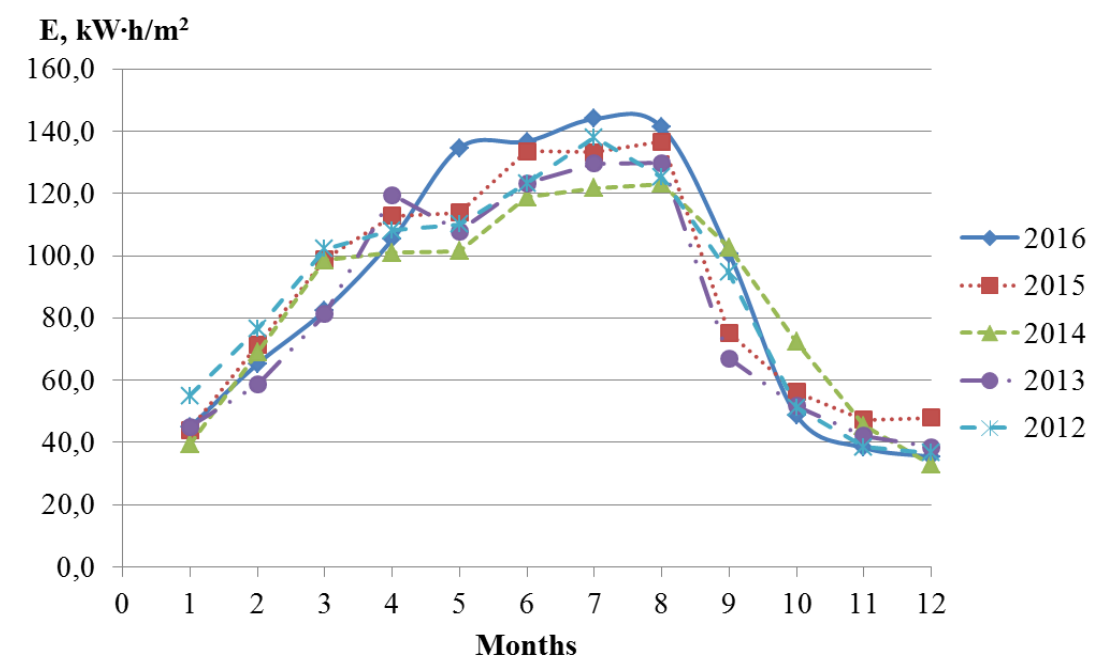

Fig. 5. Graph of changes in the energy density of solar radiation for each month in 2012-2016 


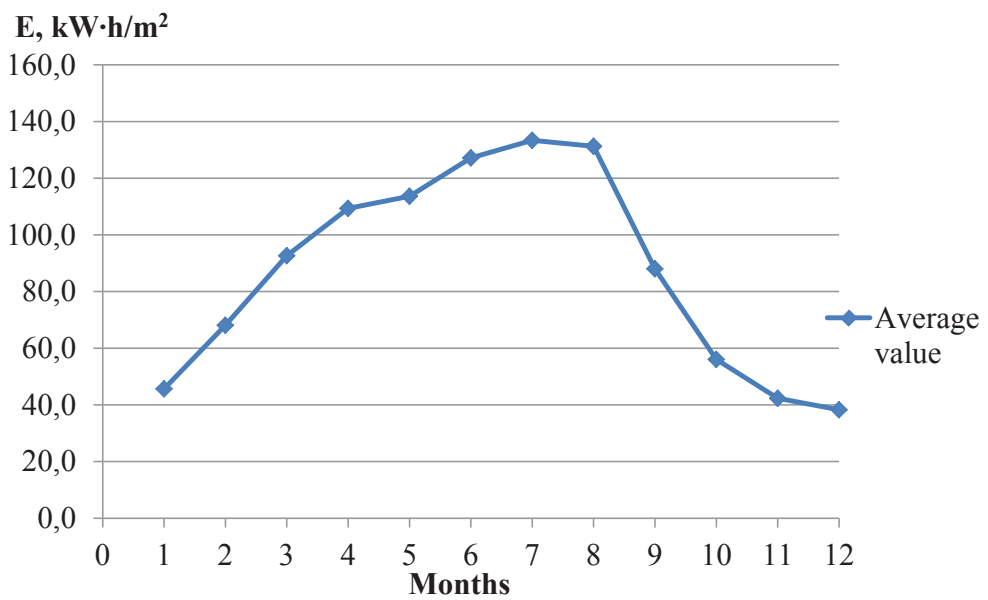

Fig. 6. Graph of the change in the average annual value of the solar energy density of the western region

Fig. 7 shows the histogram of the total annual energy of solar radiation for 2012-2016 and its average value.

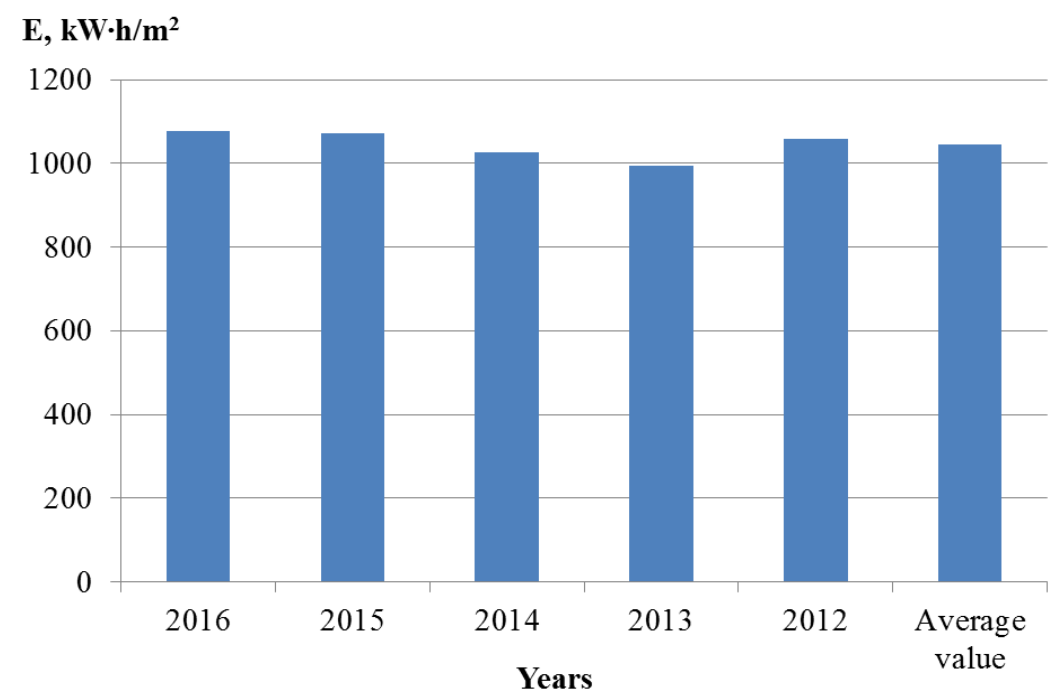

Fig. 7. Histogram of total annual energy of solar radiation for 2012-2016 and its average value

From Fig. 7 it is shown that the deviation from the average annual value of the energy density of solar radiation does not exceed $\pm 51,5 \mathrm{~kW} \cdot \mathrm{h} / \mathrm{m}^{2}$, which is $5 \%$. Therefore, for the technical and economic calculation of solar energy systems in the western region, it is advisable to use the average annual density of solar energy $1045.9 \mathrm{~kW} \cdot \mathrm{h} / \mathrm{m}^{2}$.

\section{Conclusions}

1. On the basis of a comparison of the measured values of the flux density of solar radiation and the cloud cover taken from meteorological services, a monthly analytical dependence of the mean daily flux density of solar radiation on the degree of cloudiness $E(N)$ is established. This will allow, based on the cloud data of meteorological services of other regions, to calculate the flux of solar radiation and estimate their solar energy potential.

2. The calculation of the solar energy potential during 2012-2016 of the western region of Ukraine is carried out. It is determined that the average annual density of the solar energy flux is $1045.9 \mathrm{~kW} \cdot \mathrm{h} / \mathrm{m}^{2}$, and its deviation does not exceed $5 \%$. This will allow the calculation of technical and economic parameters for the design of the solar energy system in the western region of Ukraine. 


\section{References}

[1] Meteopost (2017). Available at: http://meteopost.com/weather/archive/

[2] Vozniak, O. T., Yaniv, M. Ye. (2010). Enerhetychnyi potentsial soniachnoi enerhetyky ta perspektyvy yoho vykorystannia v ukraini. Visnyk Natsionalnoho universytetu "Lvivska politekhnika". Seriia: Teoriia i praktyka budivnytstva: zbirnyk naukovykh prats, 664, 7-10.

[3] Kozyrskyi, V. V., Martyniuk, L. V. (2012). Intensyvnist soniachnoho vyprominiuvannia, spriamovanoho na pokhylu poverkhniu. Naukovyi visnyk Natsionalnoho universytetu bioresursiv i pryrodokorystuvannia Ukrainy. Seriia: Tekhnika ta enerhetyka APK, 174 (1), 112-119.

[4] Fylenko, V. V. (2015). Do pytannia vyznachennia diisnykh helioenerhetychnykh resursiv. Problemy mashinostroeniya, 18 (1), 67-72.

[5] Zhelykh, V. M., Omelchuk, O. V., Shapoval, S. P., Venhryn, I. I. (2015). Enerhetychnyi potentsial soniachnoi radiatsii na terytorii Ukrainy. Visnyk Natsionalnoho universytetu "Lvivska politekhnika". Seriia: Teoriia i praktyka budivnytstva: zbirnyk naukovykh prats, 823, 117-121.

[6] Koval, V. P., Ivasechko, R. R., Kozak, K. M. (2015). Enerhetychna efektyvnist system pozytsionuvannia ploskykh soniachnykh panelei. Energosberezhenie. Energetika. Energoaudit, 3, 2-10.

[7] Look, D. C. (1975). Short method for the analytical determination of atmospheric model parameters. Solar Energy, 17 (4), 265-267. doi: 10.1016/0038-092x(75)90009-2

[8] Morrison, C. A., Feber, E. A. (1976). Development and use of solar insolation data in northern tatitube for south facing surfaces. Solar Energy, 17, 116-120.

[9] Holyk, O. P., Zhesan, R. V. (2009). Analiz danykh meteorolohichnykh sposterezhen za intensyvnistiu soniachnoi radiatsii v Kirovohradskomu rehioni z metoiu stvorennia systemy avtomatychnoho keruvannia avtonomnym enerhopostachanniam na osnovi soniachno-vitrovykh ustanovok. Zbirnyk naukovykh prats Kirovohradskoho natsionalnoho tekhnichnoho universytetu. Tekhnika v silskohospodarskomu vyrobnytstvi, haluzeve mashynobuduvannia, avtomatyzatsiia, 22, 164-172.

[10] Kravchenko, V. P., Kravchenko, Ye. V., Bodnar, I. V. (2016). Instrumentalne vyznachennia insoliatsii v raioni m. Odesy. Enerhetyka:ekonomika, tekhnolohii, ekolohiia, 1, 20-27.

[11] SOLARGIS (2017). Available at: http://solargis.com/products/maps-and-gis-data/free/download/ukraine

[12] Pivnyak H.H., Shkrabets F.P. (2013). Alternatyvna enerhetyka v Ukraini. Dnipropetrovsk: Natsionalnyi hirnychyi universytet, 109. 